\title{
OS GUARANI DO LITORAL NORTE DE SANTA CATARINA: TENSÕES ENTRE O USO DA TERRA E A PROPRIEDADE PRIVADA CAPITALISTA ${ }^{1}$ \\ LOS GUARANI DE LA COSTA NORTE DE SANTA CATARINA: TENSIONES ENTRE EL USO DE LA TIERRA Y LA PROPIEDAD PRIVADA CAPITALISTA
}

\section{THE GUARANI FROM SANTA CATARINA'S NORTH SHORE: TENSIONS BETWEEN LAND USE AND CAPITALIST PRIVATE PROPERTY}

\author{
Camila Salles de Faria² \\ Léa Lameirinhas Malina ${ }^{3}$
}

\begin{abstract}
RESUMO: Trata-se de uma leitura geográfica da ocupação do litoral norte do estado de Santa Catarina, que ocorre permeada pelo conflito entre a lógica indígena Guarani (uso e apropriação) e a capitalista (mercadoria, lucro e acumulação das riquezas, esta última fundamentada na propriedade privada), que coexistem e disputam esses espaços. Nesse contexto, revelamse como momentos importantes da análise os processos de expropriação e resistência do povo Guarani em relação ao uso de suas terras tradicionais, assim como a constituição da propriedade privada capitalista da terra nesta região catarinense, marcada pelo absenteísmo, pela apropriação privada de terras públicas e pelo rentismo, característicos da formação social brasileira.
\end{abstract}

Palavras-chave: Indígenas Guarani, propriedade privada capitalista da terra, expropriação, uso, resistência.

RESUMEN: Es una lectura geográfica de la ocupación de la costa norte de Santa Catarina, ocupación que está penetrada por el conflicto entre la lógica indígena Guaraní (uso y propiedad) y la capitalista (mercancía, ganancia y acumulación de riqueza, basada en la propiedad privada), que disputan estos espacios y coexisten en ellos. En ese contexto se revelan, como momentos importantes del análisis, los procesos de expropiación y de resistencia del pueblo Guaraní en relación al uso de sus tierras tradicionales, así como la constitución de la propiedad privada capitalista de la tierra en esta región de Santa Catarina, marcada por el ausentismo de propietarios, por la apropiación privada de las tierras públicas y por el rentismo, característicos de la formación de la sociedad brasileña.

Palabras clave: Indígena Guaraní, propiedad privada capitalista de la tierra, expropiación, uso, resistencia.

\footnotetext{
${ }^{1}$ Esse texto é fruto de pesquisa coletiva para a elaboração de Laudo Pericial Antropológico, coordenado por Viviane Vasconcelos, e referente ao Processo de Ação Comum Ordinária n. 2009.72.01.05799-5, da $1^{\text {a }}$ Vara Federal e JEF Cível de Joinville/Subseção Judiciária de Joinville/SC.

2 Doutoranda em Geografia Humana pela Universidade de São Paulo.

${ }^{3}$ Mestre pelo Programa de Pós-Graduação em Geografia Humana da FFLCH-USP.
} 
ABSTRACT: This article presents a geographical understanding of Santa Catarina's north coast occupation. It focuses on the conflict between the two logics that coexist and compete for the control of this space: the indigenous logic of the Guarani (use and appropriation) and the capitalist logic (commodity, profit and wealth accumulation based on private property). The article highlights two important processes. On the one hand the dispossession of the traditional lands and the resistance that the Guarani people presents against it. On the other hand the establishment of capitalist private ownership of land that is marked by the absenteeism, the private appropriation of public lands and the rentier economy that characterize the Brazilian social formation.

Keywords: Indian Guarani, capitalist private property of the land, expropriation, use, resistance.

\section{Introdução}

A presença dos indígenas Guarani ${ }^{4}$ no litoral norte de Santa Catarina é marcada pelo processo de sua expropriação desde os tempos do Brasil colônia. Porém, neste texto trataremos especialmente do recorte temporal entre fins do século XX e início do XXI, por ser o período em que os indígenas ali presentes narram os acontecimentos.

A expropriação/expulsão dos Guarani não se resume a ações bélicas, posto que é marcada também por uma violência cotidiana, intrínseca a este processo, que tem como conteúdo primordial a negação do direito territorial Guarani em favorecimento ao direito da propriedade privada capitalista da terra.

Trata-se, portanto, de uma leitura geográfica da ocupação dessa região que ocorre permeada pelo conflito entre duas lógicas diferenciadas: a indígena Guarani (uso e apropriação) e a capitalista (mercadoria, lucro e acumulação das riquezas), que coexistem e disputam esses espaços.

A lógica indígena Guarani de ocupação resiste e se realiza no uso de suas terras baseado em sua cultura, o que se revela como contestação da lógica capitalista hegemônica. Ao mesmo tempo, a lógica capitalista,

\footnotetext{
${ }^{4}$ Ressalta-se que segundo convenção internacional os nomes de povos indígenas não recebem marca de plural e se iniciam em letra maiúscula.
} 
fundamentada na propriedade privada da terra, realiza-se nos espaços pela sua constituição através da expropriação e dos "cercamentos".

Atualmente são dez aldeias Guarani na região, totalizando aproximadamente 400 indígenas 5 . No entanto, focar-se-á neste texto apenas oito delas - as quais estão em litígio, sob ações judiciais - contidas nas quatro Terras Indígenas (TIs) em processo de demarcação. Mesmo assim, faz-se necessário ressaltar a importância das relações de troca e parentesco entre as aldeias da região como um todo.

As quatro Terras Indígenas ${ }^{6}$ totalizam aproximadamente 9.300 hectares e localizam-se nos municípios de Araquari, Balneário Barra do Sul e São Francisco do Sul. São elas a Terra Indígena Piraí (aldeia Tiaraju), a Terra Indígena Tarumã (aldeias Tarumã e Tarumã Mirim), a Terra Indígena Pindoty (aldeias Pindoty, Yvapuru, Jabuticabeiras e Conquista) e a Terra Indígena Morro Alto (aldeia Morro Alto), conforme se observa no Mapa 1.

\footnotetext{
${ }^{5}$ Segundo os dados de 2013 da Secretaria Especial de Saúde Indígena (Sesai), eram 352 índios, no entanto, o órgão contabilizou apenas sete aldeias, nas quais prestou atendimento nessa região.

${ }^{6}$ Os estudos de demarcação dessas TIs se iniciaram no final da década de 1990, mas não tiveram anuência dos próprios Guarani e por isso foram refeitos. Os relatórios, reelaborados em 2004, foram publicados no Diário Oficial da União em 2008. No ano seguinte, foi publicada a portaria declaratória de suas posses permanentes. No entanto, em 2010, o próprio ministro que assinou a portaria declaratória da TI Morro do Alto a cancelou. Concomitantemente a esses processos administrativos há o processo judicial, relativo às quatro TIs, o que torna morosa a posse plena dos indígenas de suas terras.
} 
130 AGRÁrIA, São Paulo, No. 19, 2013 FARIA, C. S. e MALINA, L. L.

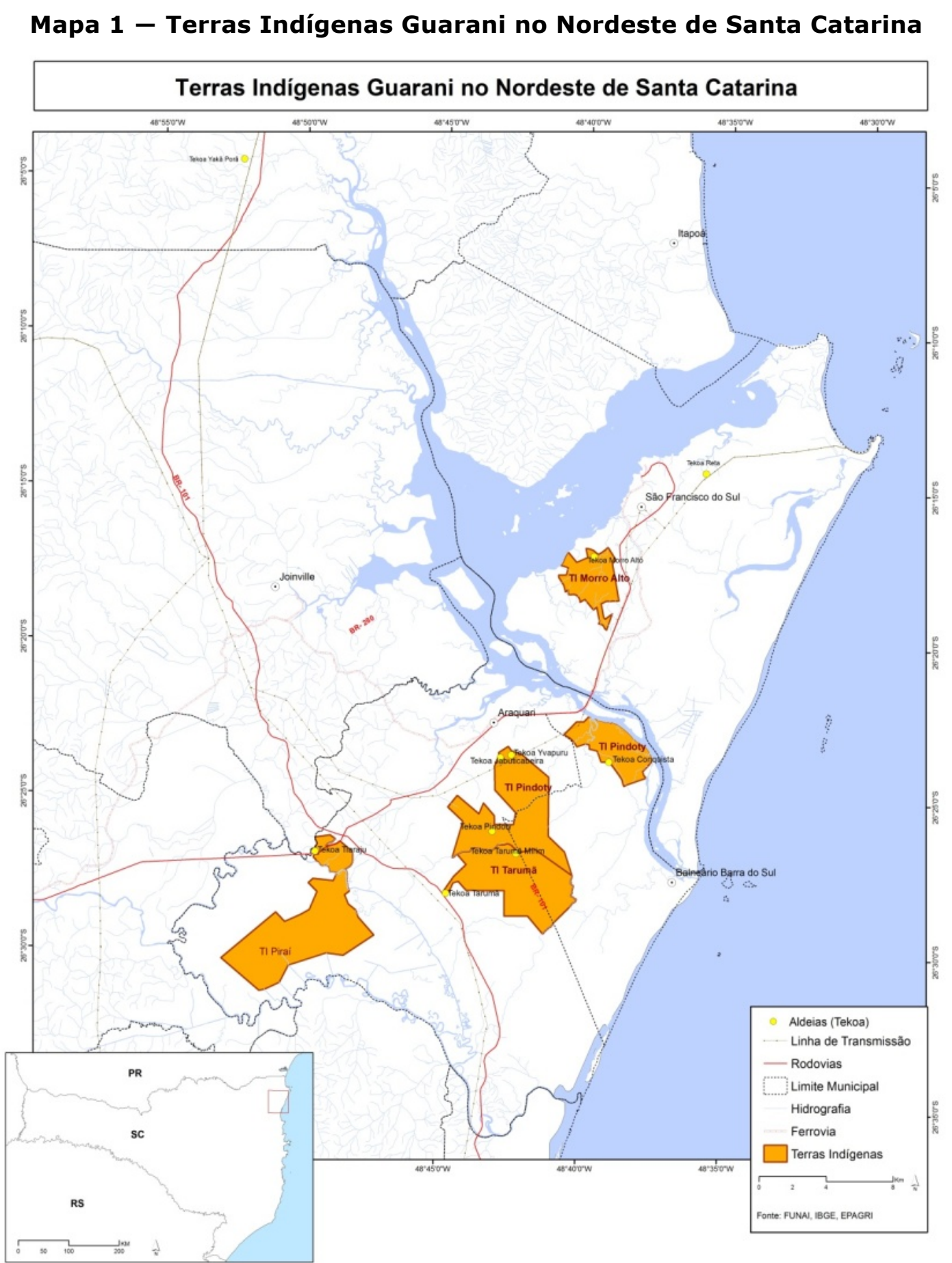

Fonte: Funai, IBGE, Epagri.

O presente artigo, a fim de analisar a disputa entre essas lógicas e suas formas de uso, apropriação e domínio da terra e do território, divide-se em dois momentos que se revelaram importantes para a análise: o primeiro trata dos processos de expropriação e resistência do povo Guarani em relação ao uso de suas terras tradicionais; e o segundo da constituição da propriedade 
privada capitalista da terra nesta região catarinense, marcada pelo absenteísmo, pela apropriação privada de terras públicas e pelo rentismo característicos da formação social brasileira.

\section{O processo de expropriação dos indígenas Guarani}

O processo de expropriação se apresenta historicamente combinado com a exploração e a violência. Este não se resume apenas a um ato, por ser um processo composto por diversas tentativas, que se reatualiza (ganha novos conteúdos), permanecendo até os dias atuais.

Assim, por meio de uma leitura marxista, cabe desvelar os conteúdos do processo de expropriação dos indígenas Guarani, ressaltando as semelhanças com o do camponês - proposto por Marx (1984) -, porque também priva o sujeito de suas terras, base que constitui esse processo, mesmo diante das especificidades de cada lugar e em diferentes momentos históricos.

Cabe ressaltar que tanto para o indígena como para o camponês existe uma relação de pertencimento com a terra que os diferencia da lógica capitalista, na qual a terra, na forma de propriedade privada, proporciona auferição de renda. Porém, este pertencimento tem diferentes conteúdos para esses sujeitos sociais. Essa diferença se expressa, entre outras coisas, no fato de que, se para o camponês existe uma relação de identidade com o lugar e significado de autonomia de seu tempo e de seu trabalho ${ }^{7}$, para o indígena há, além da identidade com o lugar, o conteúdo da terra como parte integrante do seu próprio corpo, expressa na relação homem-natureza fundamentada em sua cultura. Por isso, não interessa, como a lógica

7 Conforme demonstra, por exemplo, Lopes (1960), ao analisar a constituição de parte do operariado paulistano neste momento. Vindos do meio rural, estes operários apontam de diversas formas sua falta de pertencimento à indústria, havendo incômodo com a falta de liberdade que o trabalho para os outros gera, pautado em horários e disciplina alheia. Também fica explícito, para parte destes, o desejo de retorno e a importância da possibilidade de voltar ao campo, por meio da manutenção de pequenas propriedades ou posses agrárias familiares, que mantém o elo destes operários com suas origens. 
capitalista propõe, "qualquer pedaço de terra", ou "qualquer lugar", mas sim àquela pertencente ao povo Guarani, ou seja, o lugar em que nasceram e/ou que tenham seus parentes enterrados e/ou aquela em possam encontrar a "terra sem males" e/ou aquela revelada em um sonho e/ou onde possam desenvolver o "nhandereko" (modo de ser Guarani).

Historicamente houve, em geral, a expulsão dos indígenas e camponeses de suas terras - meio de produção e de sobrevivência - , promovendo a "[...] chamada limpeza das propriedades, a qual consiste [em] varrer desta os seres humanos", banir os seus usos, obrigando-os a se tornarem vendedores de si mesmos, ou melhor, da única coisa que possuem, que é sua força de trabalho, a fim de garantir sua existência. Ao mesmo tempo, os poucos usurpadores realizam a terra como propriedade privada e como detentores de seu domínio a transformam em "negócio capitalista" (MARX, 1984).

Nesse contexto, é importante salientar que o processo de expropriação dos indígenas não resultou de imediato apenas na exploração de sua mão de obra. Em sua maioria, quando expulsos das terras que ocupavam, foram para outras áreas onde, muitas vezes, foram sujeitados novamente ao processo de expropriação, mudando-se repetidamente. Isso causou uma redução exacerbada de suas terras e os obrigou - em outro momento histórico - a vender sua mão de obra para garantir sua sobrevivência. Atualmente, a exploração de sua mão de obra se realiza por meio da implantação de cargos no interior da aldeia, decorrentes de políticas públicas, ou pelo recebimento de diárias decorrentes de trabalhos temporários.

Dessa forma, diferentemente do que ocorreu no passado, quando trabalhavam nas lavouras dos não indígenas em troca de proteção de suas terras, ou mesmo por um pedaço de terra para viver, a exploração da mão de obra indígena Guarani também se reatualiza, ganhando o conteúdo da remuneração.

Por último, sublinha-se ainda que nem todas as aldeias atualmente desocupadas sofreram processo de expropriação, algumas foram desabitadas em decorrência do modo de viver Guarani, caracterizado, entre outras coisas, 
pela mobilidade e pelas relações com as demais aldeias. Porém, destacar-seá aqui os conteúdos do processo de expropriação, enfatizando os conflitos existentes.

2.1 Os conflitos e as formações das atuais aldeias

\subsubsection{Terra Indígena Piraí}

A atual formação da aldeia Tiaraju, na Terra Indígena Piraí, se deu no fim da década de 1970 quando a parentela do indígena Francisco Quirimaco morava sob a ponte de Pirabeiraba. Sua sobrinha Lídia Timóteo, que hoje reside na aldeia Yakã Porã (município de Garuva, Santa Catarina), narrou ${ }^{8}$ que chegou um padre na localidade e ofereceu um local de moradia aos Guarani, reafirmando que se tratava de terra Guarani, e depois de os indígenas conhecerem o local, convenceu-os a ali permanecerem.Segundo a indígena, seu tio contava que o lugar já havia sido habitado pelos seus antepassados, já que havia encontrado sinais (espécies da flora ${ }^{9}$ ) considerados marcos referenciais de ocupação pretérita de seu povo.

É válido ressaltar que somente em junho de 1980 o padre firmou contrato de compra e venda com o Domínio Dona Francisca Ltda. ${ }^{10}$ para regularização da área em questão, que totalizava 8,59 hectares. Isto quer dizer que ele trouxe os indígenas para área sem ser o proprietário desta.

No final da década de 1980 o padre vendeu parte desse terreno (2 hectares) para um terceiro, não indígena, que passou a residir no local com sua família e a viver concomitantemente com os Guarani até 1996, momento em que o padre se comprometeu a vender mais 3,4 hectares do terreno à mesma pessoa e pediu aos indígenas que saíssem do local. No entanto, o

\footnotetext{
8 Durante os trabalhos da Diligência Pericial.

${ }^{9}$ Como a Lágrima de Nossa Senhora spp. (kapi’a) e o Tabaco spp. (pety).

10 O Domínio Dona Francisca será explicado na segunda parte deste texto.
} 
comprador ficou desempregado e mudou-se para outro município em busca de trabalho, regressando somente em 2001, quando chegou a dividir a casa com os Guarani, onde exercia uma pressão interna para que os indígenas se retirassem da área.

No ano seguinte (2002), quando saiu da área, moveu uma ação de reintegração de posse contra os indígenas. A ação foi ajuizada em conjunto com o padre e tem como objetivo a "[...] remoção do cacique Artêmio Brizola e demais componentes da comunidade Guarani, das terras em questão" (JUÍZO FEDERAL DA 4a VARA FEDERAL DE JOINVILLE, 2008).

Nesse ínterim, em 1996, o padre sublinhou a importância dos Guarani ocuparem uma terra maior e remeteu-se àquela pertencente à Rede Ferroviária Federal Sociedade Anônima (RFFSA), em Araquari (DARELLA et al., 2010).

A mesma proposta ocorreu de fato em 2011, quando os caciques de quatro aldeias foram levados até a fundação pertencente ao padre e, em reunião com outros autores da ação, propuseram um acordo para finalizar os conflitos fundiários na região. A proposta consistia basicamente na remoção dos Guarani das diferentes Terras Indígenas da região para que fossem todos reunidos em uma única área, pertencente à RFFSA, com aproximadamente 750 hectares, localizada às margens de ramal vicinal conhecido como Estrada do Inferninho. Segundo o próprio documento, isso tornaria suspensa qualquer necessidade com vistas à demarcação de Terras Indígenas na região, já que a demanda por terra Guarani haveria sido resolvida. Os indígenas contaram que houve muita pressão e insistência para que eles assinassem o documento, porém isso não ocorreu.

Dessa forma, nota-se que há diversas tentativas de expropriação dos indígenas do local. Revela-se como uma estratégia dos não indígenas para a constituição da propriedade privada capitalista da terra o processo no qual os indígenas asseguram a posse da terra, e depois da obtenção do documento desta, o então proprietário os expulsa ou tenta removê-los para a terra de outrem. 
Indícios desse processo se encontram na fala de Osmarina de Oliveira ${ }^{11}$, do Conselho Indigenista Missionário (Cimi) de Santa Catarina:

\begin{abstract}
Aí assim, uma coisa que a gente percebe, que a gente demorou até pra perceber, é que muitas pessoas colocavam os indígenas em cima [da terra], cediam, mas era como forma dos indígenas ficarem ocupando aquele terreno para eles, quando eles precisavam da terra, então eles pediam para os índios saírem [...] Então essa é uma sensação que a gente teve que os índios estavam ali para reservar a terra para aquelas pessoas, entendeu.
\end{abstract}

\title{
2.1.2 Terra Indígena Tarumã
}

Concomitantemente à ocupação da aldeia Tiaraju, a família dos Guarani Liberato Esquivero e Maximiniana Almeida Tataxĩ moravam em barracos à beira da rodovia BR-101, em frente ao terreno da atual aldeia Tarumã, próximo ao km 64 da BR-101. Apareceu lá um casal de paroquianos, que a exemplo do padre cedeu (oralmente) um terreno para a família dos indígenas, onde fundaram a aldeia Corveta I (atual aldeia Tarumã).

Alguns anos depois, ainda na década de 1980, a família de Liberato fundou a aldeia Corveta II, conhecida pelos Guarani por tekoa Kury'i, próxima a Corveta I, sendo uma área que eles já conheciam e utilizavam. A mudança para a Corveta II ocorreu com ajuda do padre por meio de uma kombi, a mesma que ele possui até hoje, utilizada para tarefas da Fundação e da paroquiana supracitada, conforme contou o próprio padre em 6 de fevereiro de $2014^{12}$. Nota-se que ambos levaram os indígenas a um terreno que não os pertencia.

\footnotetext{
${ }^{11}$ Entrevista realizada na Universidade Federal de Santa Catarina, em fevereiro de 2014, como parte da pesquisa para elaboração do Laudo Pericial.

12 Durante os trabalhos da diligência pericial.
} 
Sr. Aristides, atual cacique da aldeia Tarumã Mirim, contou ${ }^{13}$ como foi a história da aldeia e o processo de expropriação.

\begin{abstract}
Aí ficamos mais de três anos, lá no Corveta II, foi quando começaram a mandar a gente sair... o pessoal entrou, aí o branco, aí lá na aldeia, do índio lá, disse que entraram armados né? Entrou na aldeia do índio, com arma, aí o Dionízio, marido da Sueli, cacique, chegou lá e pediu para [não] "fazer tiro", que podia matar ele, aí não "fizeram tiro", aí no outro dia o índio já tava com medo, aí saíram para Barra do Sul.
\end{abstract}

Assim, em 1989 eles foram expropriados dessa área, que foi vendida a uma importante empresa têxtil da região, local que seria destinado ao plantio de eucalipto para o abastecimento energético da mesma ${ }^{14}$. Conforme Darella (1999), os índios foram expulsos por jagunços e após saírem atearam fogo em suas casas.

Os jagunços se anteciparam e limparam a terra, usaram de violência, expulsaram os índios para vender as áreas [para a empresa] sem quaisquer vestígios de ocupação humana anterior, não arriscando desta forma a compra-venda (DARELLA, 1999, p. 154).

Vale ressaltar que a constituição da grande propriedade atualmente sob domínio da empresa têxtil - denominada Fazenda Araquari, que é resultado da união de cinco imóveis e totaliza uma área de 800,06 hectares - de onde os indígenas foram expropriados, também foi fruto de violência contra uma família de posseiros que ali residia, que teve sua casa queimada a fim de pressionar a sua venda.

Segundo Francisco Dantas (1989), em relatório elaborado para a Fundação Nacional do Índio (Funai), os índios foram transportados em um

\footnotetext{
${ }^{13}$ Em entrevista realizada durante a elaboração do Relatório Circunstanciado de Identificação e Delimitação da Terra Indígena Tarumã (CARVALHO, 2004a, p. 52).

14 A Fazenda Araquari é uma das oito áreas da empresa para produção de eucalipto e representa menos de $0,5 \%$ do faturamento anual de 2008 .
} 
caminhão para um lote urbano no município de Balneário Barra do Sul, em propriedade da imobiliária que intermediou toda a negociação, e receberam uma quantia em dinheiro (NC\$40) $)^{15}$.

Em decorrência do número de pessoas (aproximadamente 30) e do tamanho do terreno, os indígenas estavam sem condições de plantio, vivendo em barracos de lona e sem disponibilidade de água (esta somente era possível por caridade de um vizinho conhecido por Paraíba), permanecendo no lote apenas três meses. Após este período, uma parte da família se deslocou para uma aldeia em Itajaí e depois voltou para a Corveta I, e outra foi para a aldeia Reta (município de São Francisco do Sul, Santa Catarina).

Dessa forma, o que houve na Corveta II, na Terra Indígena Tarumã, foi um processo de expropriação acompanhado de explícita violência, que levou à fragmentação dos laços sociais e de parentesco dessa família.

\subsubsection{Terra Indígena Pindoty}

A formação da aldeia Pindoty ocorreu no final da década de 1990 pela família de Benito Oliveira, que andou, em companhia de seus parentes, quatro dias e três noites pelas matas da localidade, na área pertencente à Rede Ferroviária (RFFSA). Isso porque Benito, que liderava o grupo, "procurava lugar mesmo", ele "sonhava para achar lugar para morar" e "a gente ia junto atrás disso", como afirmou Ronaldo da Silva ${ }^{16}$.

Vindos de São Francisco do Sul, de um lugar denominado Tapera, próximo ao antigo lixão atualmente desativado, os indígenas foram pressionados a sair pela Secretaria de Bem-Estar do município e pela chegada

\footnotetext{
${ }^{15}$ Em fevereiro de 2014, durante o trabalho de campo, encontramos esse terreno e Deolinda, esposa de "Paraíba", que cedia água aos índios. Essa senhora em conjunto com outro vizinho nos conduziu até o lote onde os Guarani residiram, o qual a comunidade local se refere por "terreno dos índios". Ele se encontra cercado por construções, e nele há uma pequena mata em regeneração com a presença de espécies importantes para cultura Guarani que sinalizam sua ocupação, como, por exemplo, o jerivá (pindo) e o cipó imbé (guembe).

16 Em entrevista realizada em fevereiro de 2014. Ronaldo da Silva é casado com a neta de Benito de Oliveira e atualmente é cacique da aldeia Morro Alto.
} 
de um pretenso proprietário que solicitou sua saída. Sr. Benito era temeroso e, com o intuito de evitar conflitos, preferia ocupar as terras com aquiescência dos proprietários, tendo feito isso nas diferentes localidades em que moraram - tanto na Tapera como na Reta e posteriormente em Morro Alto.

As famílias que estavam na Tapera se dividiram, tendo parte delas seguido Benito Oliveira para área da atual Terra Indígena Pindoty, em 1998, e parte se dirigido para a área de Morro Alto, em 1999. Outra parte ainda se deslocou para a atual aldeia Reta, e outra permaneceu na Tapera até ao menos 2003, conforme relatou Carvalho (2004b).

Ainda no fim da década de 1990 se formou uma nova aldeia próxima ao Pindoty, intitulada Yvapuru, a partir da qual, anos depois, foi fundada a aldeia denominada Jabuticabeiras. A Terra Indígena Pindoty, atualmente, ainda conta com a aldeia Conquista, iniciada em 2002.

O processo de expropriação nesta TI resulta, principalmente, da imposição de cercas, decorrente da expansão da propriedade privada capitalista que restringe o acesso e o uso (coleta, abertura de novos roçados, caça e pesca) dos indígenas aos locais. A presença de cercas, em sua maioria de arame farpado, e de placas proibindo a entrada dissipa o sentimento de liberdade dos Guarani, sendo comum se escutar dos mais velhos que "antes éramos livres", referindo-se às terras que sempre utilizaram e as quais, hoje, são restritas para seu uso. A fim de evitar o confronto, os indígenas deixam de ir a esses locais. Conforme narrou o cacique Inácio, da aldeia Jabuticabeira ${ }^{17}$ :

Esse é um aviso para nós: "propriedade particular, entrada proibida". Antigamente aqui era bem legal, não tinha proibido assim. Antigamente aqui nós cortávamos para fazer o bichinho (artesanato), para pegar material no mato. [...] Antigamente não tinha proibido. Andávamos para cá, para lá. [...] Eu não sei de quem é, mas antigamente a gente usava tudo. Agora a gente não usa, porque vimos esse aqui [placa], vimos aquela lá [cerca]. Nós temos medo. Porque hoje não pode mais ir no mato porque tem dono, cachorro bravo e espingarda.

\footnotetext{
${ }^{17}$ Em entrevista realizada durante os trabalhos de Diligência Pericial, em dezembro de 2013.
} 
A expropriação pelo "cercamento" traz a violência velada e aponta como tendência a negação da reprodução do indígena, visto que o "ter", propriedade privada, sobrepõe-se ao "uso", lógica indígena Guarani, através de obstáculos na paisagem (cerca e placa).

\subsubsection{Terra Indígena Morro Alto}

A formação da aldeia Morro Alto também é decorrente da saída de parte da família do Sr. Benito da Tapera (antigo Lixão) no final da década de 1990. Quando se mudaram para a Tapera (II), um pretenso proprietário apareceu pedindo que saíssem do local. Os indígenas foram à prefeitura e descobriram que não estavam ocupando o terreno cedido a Benito Oliveira, mas sim dentro de outro imóvel, de uma pessoa conhecida por possuir muitas terras na região. Essa pessoa tinha um terreno situado na localidade de Laranjeiras (atual TI Morro Alto) e aceitou trocá-lo pelo imóvel do qual os indígenas tinham o documento, que ficava no interior de sua outra propriedade, na localidade da Tapera. Ele firmou, então, contrato de cessão de uso do terreno de 2,45 hectares aos indígenas, em maio de 1999.

Assim, os Guarani fundaram Morro Alto, em área que já utilizavam para coleta, conforme afirmou o cacique. No entanto, passados alguns anos novamente chegou um pretenso proprietário e pediu para que saíssem da área. Sem entender o que estava acontecendo, principalmente porque tinham o documento da terra em mãos, os Guarani foram até a prefeitura para averiguar o ocorrido. A prefeitura de São Francisco do Sul disponibilizou um engenheiro responsável por determinar a exata localidade do terreno do contrato de cessão de uso. Após análises, este esclareceu que a área do imóvel não correspondia ao local de moradia dos indígenas, mas sim à parte de maior altitude da aldeia. No entanto, os Guarani não desocuparam a área e no local onde possuem o documento de cessão de uso construíram uma escola e um posto de saúde. 
Segundo o cacique Ronaldo da Silva, o fato de possuir tal documento ia de encontro ao modo como Benito Oliveira agia, pelo entendimento de que, ao ter a cessão de uso, diminuir-se-iam os conflitos por terra. No entanto, muitos não indígenas (jurua) vieram à aldeia dizendo serem donos da terra. Ronaldo, então, concluí que "os mais velhos dizem que antigamente os brancos matavam com armas. Hoje matam com papel" (DARELLA et al., 2010, p. 243).

Trata-se novamente do processo de expropriação, e de suas tentativas, pautadas na constituição da propriedade privada e no absenteísmo. Revelam apenas o proprietário do título e não quem realmente ocupava/usava o lugar. Soma-se a isso o fato de que os índios Guarani de Morro Alto desconhecem, "nunca viram", "não sabem onde fica propriedade" do próprio autor do processo, conforme ressaltaram durante as entrevistas.

No entanto, muitas vezes o processo de expropriação não se realiza de forma integral, traz sua negação, a resistência. Nas palavras de Martins (1980, p. 31): "[...] o nível de expropriação foi tão longe que acabou produzindo um fato político que é a resistência."

A resistência se revela como a permanência dos indígenas nas áreas em conflitos, na luta pela demarcação de Terras Indígenas e pela retomada de terras que os Guarani não detinham sua posse plena, como a formação da aldeia Tarumã Mirim, observada na foto 1 .

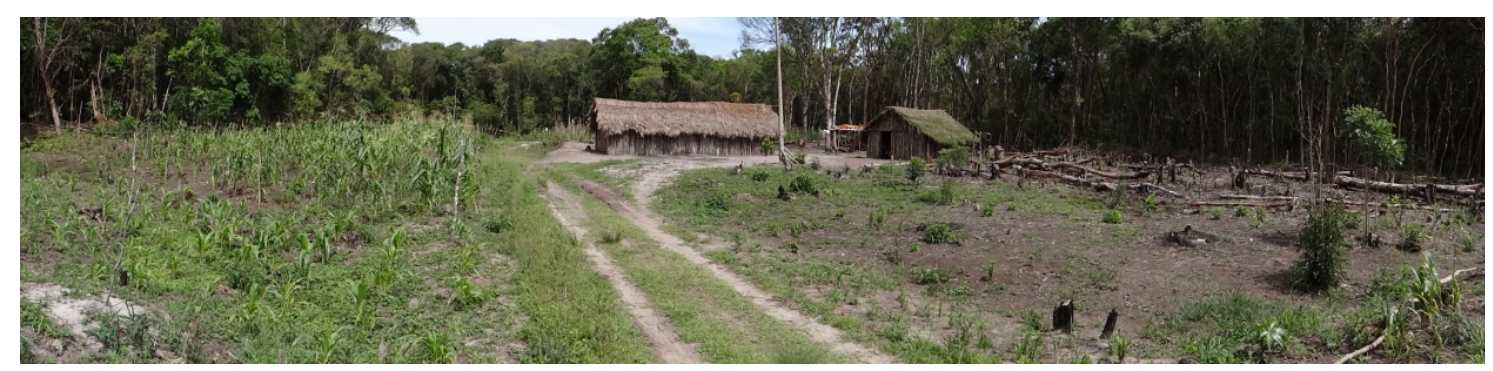

Foto 1: Aldeia Tarumã Mirim. Observa-se, ao fundo, a casa de reza (opy) construída de forma tradicional ${ }^{18}$; à esquerda, uma roça de milho tradicional (avaxiete'i); e, à direita, uma área que foi recentemente queimada, demonstrando a manutenção do sistema de roça de coivara ${ }^{19}$, também tradicional entre os Guarani. Fonte: Malina (2013).

\footnotetext{
18 Sem janelas, com paredes de barro e telhado de palmeira.

${ }^{19}$ Chamada também de sistema de corte e queima, é uma técnica itinerante de agricultura que envolve o corte e a queima da vegetação, o plantio, a colheita, o pousio e, com isso, a
} 


\section{A propriedade capitalista da terra no litoral norte catarinense}

A formação social brasileira tem como uma de suas origens a desestruturação, longa e reiterada, dos modos pelos quais os povos indígenas desenvolviam suas culturas, através de relações comunitárias de produção (FARIA; OLIVEIRA, 2009). Todos os povos indígenas que aqui viviam sofreram no embate com a chegada dos colonizadores europeus, sendo que grupos inteiros foram dizimados e muitos indígenas morreram. Os Guarani, um dos povos que ocupava a porção mais atlântica do país naquele momento (como o fazem até hoje), foram um dos primeiros a sofrer as consequências do contato.

Assim, mesmo antes da existência da propriedade da terra enquanto tal no Brasil ${ }^{20}$, com a ocupação colonial fundada na escravidão, o processo de desestruturação dos territórios destes povos já caminhava a passos largos.

Silva (2002) afirma que o avanço do capitalismo, ao modificar radicalmente a organização da exploração da terra, mudou a forma como os homens se relacionam em sociedade e com a natureza, de modo a disseminar a noção de que ocupar uma terra só seria legitimo se a ela se desse uso produtivo, entendendo esse uso, na maioria das vezes, como possibilidade de auferir lucro e renda.

A autora desenvolve que esse argumento se solidificou, entre pensadores da filosofia política, no século XIX, quando ocorriam mudanças das condições econômicas e sociais na Europa, à medida que o continente, antes caracterizado predominantemente como mercantilista, dava lugar à hegemonia do capitalismo industrial (Ibidem, 2002).

Assim, no mesmo momento em que no Brasil se gestou uma mudança que tornou a terra equivalente de mercadoria, ou seja, passível de compra e

regeneração da capoeira, já que não se arrancam os tocos da vegetação anterior e esses rebrotam com o passar do tempo.

20 Já que a primeira forma de legislação sobre a terra no país foi a constituição das sesmarias, que davam apenas direito de uso às terras reais, mediante algumas condições, tais quais seu uso produtivo (FARIA; OLIVEIRA, 2009). 
venda, e com a proibição da apropriação privada das terras públicas (com a Lei de Terras $^{21}$, de 1850), a ideia da propriedade privada enquanto forma exclusiva e excludente também se cristalizava, não havendo mais lugar para terras não cercadas, "livres", e nem para seus habitantes (Ibidem, 2002).

Nesse contexto se faz relevante atentar novamente para a teoria marxista, que coloca a propriedade privada da terra como componente estruturante do modo capitalista de produção. Marx discorreu, especialmente no capítulo sobre a acumulação originária do Livro I d'O Capital (MARX, 1984), a respeito do processo lógico e histórico de cercamento das terras na Inglaterra e sua relação com a constituição do capitalismo, pautado na separação entre os produtores e seus meios de produção.

O autor também discorreu n'O Capital (MARX, 1986) sobre o fundamento e os desdobramentos da existência da renda fundiária sob este modo de produção, demonstrando que ela permite aos proprietários de terras auferirem parte da mais-valia global produzida pela sociedade mesmo sem colocar a terra para produzir, e conformando-os como classe social constituinte do capitalismo.

Fica evidenciado, a partir destes escritos do autor que, para se reproduzir, o modo capitalista de produção precisa que os produtos e bens naturais tornem-se privados, para que possam entrar no processo de troca de mercadorias como bens escassos; afinal, se todos pudessem ter acesso a eles sem pagar (pelo fato de não terem donos), a troca não poderia se constituir como momento fundamental de sociabilidade. Ao mesmo tempo, também fica explicitado que a terra, sendo equivalente de mercadoria, posto não ser fruto do trabalho humano, possui especificidades nesta relação. Nas palavras de Martins (1986, p. 32-33):

A terra transformada em mercadoria tem efeitos bem diferentes das outras mercadorias que se caracterizam por serem produtos do trabalho humano. A terra é uma mercadoria completamente distinta das demais. A diferença está em que a terra não é produto do trabalho, é finita e

${ }^{21}$ Cf. Silva (1996) e Martins (2004). 
imóvel. É uma mercadoria que não circula; em seu lugar circula o seu representante, o título de propriedade. O que se compra e vende não é a própria coisa, mas o seu símbolo. Todas as verdadeiras mercadorias se realizam na sua utilidade e na sua utilização; elas se realizam nas mãos de quem as possui e usa. A terra não é propriamente mercadoria, mas equivalente de mercadoria. Para que possa produzir renda que é o seu uso capitalista - a terra não exige que o ter e o usar estejam juntos. Nas outras mercadorias, o ter é condição do usar e o usar é a realização do ter; no caso da terra, na sociedade capitalista (e é dela que estamos falando), não é necessário que estejam juntos [grifos do autor].

A partir daí, ganha força novamente o argumento já apresentado, da necessidade da violência e da expropriação para a reprodução desse modo de produção, a fim de garantir a existência da propriedade da terra e, com ela, a produção de capital via extração de renda (OLIVEIRA, 1997; 2007; 2009), em que pesem as especificidades com que isso ocorre em diferentes locais e momentos históricos.

Atualmente, no Brasil, é inelutável reconhecer a primazia que a terra possui como fator de produção no projeto político hegemônico de desenvolvimento do país, em suas diversas dimensões (política, econômica, jurídica, ideológica). Os processos de apropriação de terras e de cristalização da propriedade privada são centrais neste projeto capitaneado pela ação do Estado (SOUZA, 2014, p. 14) em aliança com setores que personificam o capitalismo rentista ${ }^{22}$ no país.

A fala de Carlos $^{23}$, Guarani morador da aldeia Conquista (TI Pindoty), expõe, de maneira dramática e cabal, como a forma capitalista de apropriação privada da terra, qual seja, a propriedade privada, mantém-se atualmente repondo a tendência à impossibilidade (que, enquanto tendência, não se realiza plenamente) de reprodução de outras lógicas de entendimento e apropriação do espaço e do território.

${ }^{22}$ Cf. Martins (1994; 2004).

23 Em entrevista realizada durante os trabalhos de Diligência Pericial, em fevereiro de 2014. 


\begin{abstract}
Nhanderu [Deus] não criou o rio assim, não criou a mata, e não criou a terra pra se vender. Como é que o cara fica achando que a terra é dele, que a mata é dele, que os bichinhos são dele. Isso aí não tem lógica nenhuma, nenhuma, até pro governo não tem lógica. Não pode dizer que é dono da terra. Nhanderu [Deus] não criou isso aí, ele não falou assim: "Ô, essa terra aqui, esse pedacinho aqui é pra você, pode fazer, pode ir no cartório e assinar que a terra é sua." Não existe isso. Isso aí é uma [...] é falta de respeito não só pra nós, mas diante de Nhanderu [Deus]. Isso aí que a gente, quando fala essas coisas, até dá vontade de chorar, mas, chorar não vai resolver nada. Brigar também não vai resolver nada, só vai piorando. Mas o que a gente tem esperança é que isso seja reconhecido, que de fato a gente tenha onde morar também, nós somos brasileiros também. Nós somos, eu não digo que eu sou dono da terra, que somos donos da terra, mas de fato a gente tem também direito de viver.
\end{abstract}

A fala anterior capta, entre outras coisas, justamente a maneira excludente e exclusiva que a propriedade privada (sendo ela juridicamente legítima ou não) ganha diante da lógica Guarani (e dos povos originários, em geral) de apropriação e de uso da terra. Isso porque, na primeira forma, a terra pertence ao proprietário que a comprou ou dela se apossou privadamente, e na segunda pertence às divindades, conforme a cosmologia dos povos indígenas, que a criou para que esses vivessem nela e dela.

Ao mesmo tempo, é o lugar central que a propriedade fundiária ocupa que faz, em grande medida, com que a luta pela demarcação de Terras Indígenas se torne a principal pauta desses povos atualmente, por ser o uso tradicional de suas áreas uma questão primordial para sua reprodução enquanto povo - garantia do seu "direito de viver", como exposto pelo Guarani acima; apesar das demarcações representarem também, enquanto forma, contraditoriamente, "[...] frações do território capitalista para aprisionar o território liberto indígena" (OLIVEIRA, 2007, p. 155). Posto isso, não se pode desconsiderar que, atualmente, a demarcação se revela para os indígenas como a possibilidade efetiva do uso de suas terras fundamentado em sua cultura.

Já se apresentou a lógica Guarani de ocupação desses espaços e os conflitos decorrentes dos processos de expropriação recentes vividos por eles. Cabe agora, entendendo o lugar central que a propriedade fundiária 
possui no Brasil atualmente, atentar para a constituição da propriedade privada da terra no litoral norte de Santa Catarina, que não foge à regra geral do país, onde foram e são diversas e complexas as formas de sua realização, pautadas, entre outros processos, na separação entre o domínio (título) e a posse (uso) e em diversas inconsistências jurídicas ${ }^{24}$.

3.1 Formas de constituição da propriedade privada no litoral norte catarinense

Destaca-se, em primeiro lugar, que o litoral norte de Santa Catarina, também chamado de região nordeste, foi exemplar em relação ao processo descrito por Silva (2002) de legitimação da usurpação de espaços ocupados por povos originários no século XIX. A autora aponta que, naquele momento, os Estados em formação na América passaram a aplicar o conceito de "espaços vazios" para estimular a imigração europeia, não poupando suas populações originárias. Portanto, relaciona-se aqui esse processo ao que Marx chama de "limpeza das propriedades", apontado anteriormente, que leva a terra a se tornar "negócio capitalista".

Atualmente, esta porção do estado abriga a cidade mais populosa de Santa Catarina, Joinville, conhecida pela grande imigração alemã ocorrida no século XIX. Grande parte da historiografia desta região se concentra justamente na chegada de europeus que desbravaram este "espaço vazio" e, a partir dele, construíram um dos centros econômicos mais pujantes do país.

Um dos momentos da pesquisa referente às áreas indígenas em litígio foi o levantamento do histórico da ocupação não indígena nas quatro TIs em tela ${ }^{25}$. Para isso, foi necessário obter o maior número de registros cartoriais

\footnotetext{
24 Sobre diversas formas de irregularidades relacionadas à apropriação privada de terras públicas, fator constituinte da formação da propriedade fundiária no Brasil, ver Faria e Oliveira (2009) e Oliveira $(1997 ; 2007 ; 2009)$.

25 Vale ressaltar que, a despeito da importância do estudo da constituição da propriedade privada da terra e das descobertas relevantes que ele traz, o direito dos povos indígenas a suas terras tradicionais é anterior e independente à qualquer titulação de origem particular. $\mathrm{O}$ artigo 231 da Constituição Federal de 1988 determina, em seu parágrafo quarto, que "[...] as
} 
possíveis, e mesmo com a dificuldade latente para acessá-los ${ }^{26}$, foi possível compreender, a partir dos documentos observados, algumas origens de sua titulação.

As cadeias dominiais aventadas remetem a titulações realizadas pelo estado de Santa Catarina, através de quatro maneiras distintas, que serão explicadas e exemplificadas mais à frente. São elas: concessões por sesmarias, até 1822 (FINDLAY, 2007); doação ao Domínio Dona Francisca; regularização das posses em terras devolutas (até 1931); e venda de terras devolutas através do Instituto de Reforma Agrária de Santa Catarina (IRASC), de 1961 até 1978.

A partir da Constituição de 1891, as terras devolutas se tornaram atribuição dos estados (e não mais da União), e o limite máximo da área de posse passível de regularização ficou determinado em 100 hectares. Silva (1996, p. 300) afirma que a mudança de jurisdição sob as terras devolutas acarretou profundas consequências para os povos indígenas:

\begin{abstract}
Despreocupados com os direitos dos índios brasileiros ao território que ocupavam, os constituintes entregaram aos estados juntamente com as terras devolutas aquelas que na realidade estavam por eles ocupadas há séculos. Esse dispositivo constitucional teve efeitos catastróficos para as populações indígenas, especialmente aquelas que se encontram em regiões que o desenvolvimento capitalista iria rapidamente transformar.
\end{abstract}

Findlay (2007) ressalta que em meados do século XIX, no município de Araquari:

\footnotetext{
terras de que trata este artigo são inalienáveis e indisponíveis, e os direitos sobre elas, imprescritíveis". No parágrafo sexto, expõe que: "São nulos e extintos, não produzindo efeitos jurídicos, os atos que tenham por objeto a ocupação, o domínio e a posse das terras a que se refere este artigo, ou a exploração das riquezas naturais do solo, dos rios e dos lagos nelas existentes, ressalvado relevante interesse público da União, segundo o que dispuser lei complementar, não gerando a nulidade e a extinção direito a indenização ou a ações contra a União, salvo, na forma da lei, quanto às benfeitorias derivadas da ocupação de boa-fé."

${ }^{26}$ É fundamental salientar que não tivemos acesso à totalidade dos registros da área, e nem tempo, diante do prazo de entrega do relatório pericial, para analisar a fundo todo o material coletado.
} 
[...] a ocupação de terras [estava se] multiplicando e ampliando, assim, os latifúndios. Essa ocupação não se deu apenas para fins produtivos, ela representava, também, o aumento do prestígio e do poder econômico de seus proprietários.

A autora (2007, p. 4) revela, através do Relatório da Província, que "[...] raro é quem aqui é proprietário, e quase todos cultivam pouco, mas cultivam por sua própria conta". Sendo assim, partes dessas posses puderam ser regularizadas até 1931, segundo o Decreto Federal n. 19.924.

Antes de adentrar nas duas formas específicas de constituição da propriedade da terra nestes locais, quais sejam, o Domínio Dona Francisca e a regularização de terras devolutas pelo IRASC, ainda pode-se apontar uma questão pertinente à relação entre a constituição e legitimação da propriedade privada naquela região e a ocupação Guarani.

Trata-se do caráter absenteísta dos proprietários em grande parte das terras da região, segundo análise cartorial efetuada, o que significa dizer que muitos dos registros encontrados apontam como local de moradia de seus proprietários não a própria área registrada, mas sim outros lugares, municípios e estados. Essa característica é aqui salientada, pois, além de ser uma das marcas históricas da ocupação territorial rural desde o Brasil colonial, o caráter absenteísta dos proprietários, tendo ou não a terra um caráter produtivo, está associada, nestes casos, a objetivos econômicos que vão desde a especulação fundiária, o uso da terra como reserva patrimonial, mas o não envolvimento do proprietário na vida local.

Esse caráter absenteísta contrasta com o uso efetivo feito pelos indígenas de seu território e está relacionado ao desconhecimento tanto dos proprietários em relação à existência dos indígenas no local quanto dos indígenas que habitam e usam as terras em relação aos proprietários e aos locais de suas propriedades, conforme demonstra a história da parte da família de Benito Oliveira que fundou Morro Alto. 


\title{
3.1.1 O Domínio Dona Francisca
}

O Domínio Dona Francisca foi criado a partir da doação de uma área de 25 léguas quadradas e 3 mil braças pelo Império do Brasil à Princesa Dona Francisca (irmã de D. Pedro II), quando de seu casamento com o Príncipe François Ferdinand Phillipe Louis Marie, de Joinville (cidade situada na França), em 1840. Tal doação ocorreu segundo a Lei n. 166 de 20 de setembro de 1840, que previa, entre os dotes das princesas, a fundação de patrimônio em terras pertencentes à nação.

Ficker (2008, p. 24) aponta que em 1845 o Presidente da Província de São Francisco do Sul já havia indicado uma área contígua de 25 mil léguas para instalação do Domínio ${ }^{27}$, de terras devolutas, ricas em madeira e também em minerais, localizadas ao longo da "[...] linha de defesa contra os bugres". Segundo Silva, Perini e Agostini (2003, p. 125), a instalação do Domínio (e posteriormente, da Colônia D. Francisca, que será explicada adiante) se insere no longo histórico de expropriação e violência contra os indígenas no Brasil Colonial e Imperial:

\begin{abstract}
Ao sul da baía da Babitonga e próximo ao canal do Linguado, hoje Araquari, vamos encontrar os índios carijós ${ }^{28}$, de linhagem tupi-guarani, com suas inúmeras técnicas que foram apropriadas, sobretudo pelos portugueses, tal como a cestaria empregada para a pesca e a fabricação da cerâmica. A expressão desta cultura indígena, não só na produção da cerâmica, mas também nos adereços e no grafismo corporal, permanece através de registros de alguns aspectos desta etnia quase dizimada quando da fundação da Colônia Dona Francisca.
\end{abstract}

Em 1848, por conta da revolução eclodida na França, que levou à queda do Rei Luiz Felipe, o príncipe de Joinville se refugiou em Hamburgo

\footnotetext{
${ }^{27}$ A área indicada para a localização do Domínio Dona Francisca ficava entre os rios Pirabeiraba e Itapocu e totalizava 155.812 hectares (CONSELHO NACIONAL DE GEOGRAFIA; CONSELHO NACIONAL DE ESTATÍSTICA, 1957-64, s/p), parte delas ocupadas por posseiros e sesmeiros, conforme atestam Findlay (2012), Guedes (2007) e Ficker (2008).

${ }^{28}$ Há um debate na antropologia sobre as denominações de povos indígenas, que aponta que os Guarani antes do século XVII também eram conhecidos como Carijó (LADEIRA, 2007).
} 
(Alemanha) e decidiu explorar a área dotal no Brasil. A Alemanha, paralelamente, também passava por séria crise econômica, havendo proliferado o número de empresas colonizadoras nas Américas para trazer imigrantes ao "novo mundo". Nesse contexto, o príncipe cedeu oito léguas quadradas do Domínio Dona Francisca para efetivação de colonização por europeus, em 1849. Em 1850 foi aprovado o contrato de vinda dos imigrantes pelo governo imperial brasileiro e em 1851 fundou-se a Colônia Dona Francisca - origem, entre outras, da cidade de Joinville - com a chegada dos primeiros imigrantes. A empresa de colonização responsável pelo projeto foi a Sociedade Colonizadora em Hamburgo.

A história revela que houve uma diferenciação em relação à intensidade da ocupação não indígena na Colônia e no restante do Domínio, principalmente no seu limite sudoeste. Segundo Ficker (2008, p. 49), os colonos tinham a "proteção" da empresa colonizadora, a qual também fornecia "[...] os objetos de primeira necessidade, como ferramentas, sementes e alimentos a preços módicos", diferentemente do que ocorria com a venda de terras fora da Colônia.

Segundo materiais aventados no Arquivo Histórico de Joinville ${ }^{29}$, até o ano de 1929 houve uma maior demarcação dos lotes na margem direita do rio Piraí (abrangendo terras da TI homônima) e esparsos lotes demarcados ao longo dos afluentes na margem esquerda, porém, isso não se traduzia, necessariamente, como venda ou ocupação de fato, pois segundo o livro da empresa os lotes nas margens do rio Piraí começaram a ser vendidos em 1942.

Ramos (2006, p. 135) afirma, em relação à área do Domínio, que eram:

Terras essas sobre as quais não houve o controle, por parte do Estado, após a mudança do regime político em 1889, carecendo diversas áreas, até hoje, a devida regularização. Da mesma forma, continua desconhecida a real situação das

\footnotetext{
${ }^{29}$ Mapas e livros de arrendamento e venda de lotes do Domínio Dona Francisca.
} 
terras concedidas à Sociedade Colonizadora Hamburgo, fundada em 1849 e responsável pela colonização sistemática de emigrantes alemães dirigidos para Santa Catarina.

Os primeiros dados cartoriais acessados da área do Domínio Dona Francisca são somente da década de 1930 e, ainda assim, sem localização precisa, fato que se repete em transcrição de 1957, na qual se registra a venda de toda área restante de propriedade dos herdeiros do príncipe de Joinville para uma empresa recém-fundada, denominada Domínio Dona Francisca Ltda. Foram transmitidos 6.410 hectares em terras dos municípios de Araquari, Jaraguá do Sul, Guaramirim e Joinville. Esta transcrição se refere a "sucessivos inventários" decorrentes de herança do príncipe de Joinville e da princesa Dona Francisca.

Segundo dossiê encontrado no Arquivo Histórico de Joinville produzido pela empresa Domínio Dona Francisca Ltda., a década de 1980 foi marcada pela divisão, já que um dos sócios vendeu parte da empresa a um corretor de imóveis, que se responsabilizaria pelas terras nos municípios de Joinville e Araquari, e forneceu uma procuração a uma terceira pessoa, dando-lhe direitos sobre 3.400 hectares localizados nos municípios de Jaraguá do Sul, Corupá, Schroeder e Guaramirim. Esta procuração resultou na venda de títulos de 60.000 hectares, fruto de um esquema com indícios de estelionato, falsificação de documentos públicos, envolvimento de cartórios e tabelionatos e sonegação de impostos (a empresa deve $\mathrm{R} \$ 50$ milhões somente à Jaraguá do Sul, dos quais R\$33 milhões são de Imposto Territorial Rural ${ }^{30}$ ).

No município de Araquari foi localizado o Inquérito Civil Público $\mathrm{n}$. 06.2009.004834-0 de 2011, ainda em aberto, que visa apurar eventual fraude em registros imobiliários, tendo como parte o Domínio Dona Francisca Ltda. O Inquérito questiona uma das matrículas de origem do Domínio, alegando que não há como comprovar sua existência, já que ela não possui características e confrontações.

\footnotetext{
30 No documento constam os seguintes números de processo: 026.00.001088-5 e 036.03.005564-0, execução fiscal n. 2006.72.01.003240-7/SC.
} 
Assim, é possível perceber que a constituição do Domínio Dona Francisca e seus desdobramentos reforçam o argumento da existência de formas escusas de apropriação privada da terra no país, além de seguir a tese da existência de "espaços vazios" a serem ocupados, desconsiderando seus diferentes usos e as disputas deles decorrentes.

\subsubsection{A regularização de terras devolutas pelo IRASC}

Em 1961, o estado de Santa Catarina, por meio da Lei n. 2.939, de 9 de dezembro, criou o Instituto de Reforma Agrária de Santa Catarina (IRASC). Este passou a ser o órgão responsável por administrar as terras devolutas do estado e pela regularização das posses nessas áreas. Segundo Campos (2002, p. 119), o IRASC "[...] possibilitou a concessão de títulos de domínio a interessados, sem muitas exigências, sob pagamento em dinheiro". Osni Machado, ex-funcionário do Instituto, em entrevista a André Souza Martinello, realizada em 2007 (Mimeo ${ }^{31}$ ), sintetiza as ações do IRASC:

O IRASC regularizava terras devolutas. Uma pessoa que ocupava uma terra muito tempo, fazia a regularização pelo IRASC; era feito um processo em que eram ouvidas as partes assim, que limitavam a terra da pessoa, e ali era feita audiência, era publicado no Diário Oficial toda, tinha um processo com a assinatura dos envolvidos nos limites da pessoa. No terreno dessa pessoa. Se não houvesse contestação, era declarado como terra devoluta, e o Estado emitia um título definitivo de posse daquela área, para a pessoa registrar em cartório a terra regularizada. Mas ele pagava por essa, pagava um ano, dois, três, quatro, cinco, dependendo da situação, então era bem assim, acessível para a pessoa pagar naquele tempo.

\footnotetext{
${ }^{31}$ A entrevista foi feita durante a realização do Trabalho de Conclusão de Curso de Licenciatura em História intitulado "Política agrária e imigratória nas colônias japonesas de Santa Catarina (1961-1978)", do Centro de Filosofia e Ciências Humanas da Universidade Federal de Santa Catarina, apresentado em 2007.
} 
Ou seja, aparentemente, o estado regularizava as terras devolutas mediante sua venda sem antes ter cartografado que áreas eram essas e sem um planejamento político do que se esperava para seu uso futuro.

A lei de criação do IRASC determinava como uma de suas atribuições "a colonização das terras devolutas" (artigo 1), através da venda de terras. Segundo o artigo 10, dar-se-ia especial atenção às áreas devolutas por agricultores que as utilizam, "[...] regularizando-Ihes a situação, nos termos deste artigo, por requerimento dos interessados ou independente deste, uma vez que não excedam 100 (cem) hectares". No Arquivo Público de Santa Catarina (sediado em Florianópolis), ao pesquisar somente as áreas sobrepostas às Terras Indígenas em questão, foram encontrados 17 títulos emitidos pelo IRASC ao mesmo proprietário, totalizando 466,24 hectares no município de Araquari. Além disso, também foi possível ter acesso à regularização de posse feita pelo órgão à outra empresa, após já ter vendido mais de 100 hectares a ela.

Também desta origem advém três títulos emitidos pelo IRASC ao mesmo proprietário, totalizando 322,03 hectares, que conformam parte da grande propriedade atualmente sob domínio da referida empresa têxtil na TI Tarumã. No Arquivo Público de Santa Catarina foi possível localizar o processo 45.493, de 1968, que afirma que este requerente "[...] não é posseiro da área requerida na inicial, porém, o terreno medido e demarcado é anexo ao de sua propriedade, e desejando ampliar sua propriedade requereu a referida área".

\subsubsection{Outras inconsistências encontradas}

Outras inconsistências em relação à legislação também foram encontradas na pesquisa das propriedades sobrepostas a terras tradicionais Guarani. Chamou atenção, por exemplo, a transcrição feita de acordo com mandado judicial por usucapião a uma empresa madeireira, de 1.069 hectares, de 1969; e em 1983, à mesma empresa, com área de 448,9 
hectares. Vale lembrar que o Estatuto da Terra, em seu art. 98, da Lei n. 4.504/1964, prevê a regularização de posses somente para:

[...] aquele que, não sendo proprietário rural nem urbano, ocupar por dez anos ininterruptos, sem oposição nem reconhecimento de domínio alheio, tornando-o produtivo por seu trabalho, e tendo nele sua morada, trecho de terra com área caracterizada como suficiente para, por seu cultivo direto pelo lavrador e sua família, garantir-lhes a subsistência, o progresso social e econômico, nas dimensões fixadas por esta Lei, para o módulo de propriedade.

Além disso, encontraram-se também transcrições sem origem; transcrições com origem em inventário pós-Código Civil de 1916, o qual já exigia o registro no livro 3; diversas transcrições realizadas de acordo com o art. 244 do Decreto 4.857 de $1939^{32}$, porém, sem nenhuma menção ao modo de aquisição do imóvel ou à sua transcrição anterior e sem apresentação de fato gerador para acioná-lo; legitimação de posse em área maior de 100 hectares após 1891; matrícula ou transcrição sem área; dois terrenos não contíguos registrados na mesma matrícula/transcrição, o que não atende ao requisito legal; e transcrição e matrícula com área imprecisa.

\section{Considerações finais}

Objetivou-se evidenciar, a partir da história recente de conflitos entre a constituição da propriedade privada capitalista e o uso da terra Guarani, que essas duas formas de apropriação territorial estão inevitavelmente em conflito, posto que expõem lógicas distintas e antagônicas de uso e destinação da terra.

\footnotetext{
32 Art. 244: "Em qualquer caso, não se poderá fazer a transcrição ou inscrição sem prévio registro do título anterior, salvo se este não estivesse obrigado a registro, segundo o direito então vigente, de modo a assegurar a continuidade do registro de cada prédio, entendendose por disponibilidade a faculdade de registrar alienações ou operações dependentes, assim, da transcrição anterior."
} 
A partir da história recente de expropriações territoriais Guarani, explicitou-se algumas estratégias e consequências do conflito destas lógicas, como a utilização da ocupação indígena para garantir a posse da terra a fim de assegurar ao seu futuro proprietário (não indígena) o domínio da área, processo que culmina na expulsão ou remoção dos Guarani (TI Piraí); processos de violência explícita, com esbulho e queima literal da área que os indígenas ocupavam, ou seja, a "limpeza das propriedades" (TI Tarumã); e a violência velada dos cercamentos, que leva à tendência de negação da reprodução indígena (TI Pindoty).

Ao mesmo tempo, considerou-se que o processo de expropriação traz inelutavelmente consigo a sua negação, a resistência. Esta é expressa na permanência dos indígenas nas áreas de conflito, na retomada de áreas anteriormente ocupadas e na luta pela demarcação de suas terras. Salientouse ainda que estas últimas são, contraditoriamente, apenas frações delimitadas do território liberto indígena e condição necessária à reprodução desses povos enquanto sociedades diferenciadas em tantos aspectos, tais como a cultura, a política, a relação com natureza etc. que, no caso dos Guarani, conforma o nhandereko.

Por fim, fica explícito que a propriedade privada capitalista da terra se coloca como barreira à reprodução dos Guarani, em um contexto em que ela possui importância inegável tanto no plano econômico como no plano político no país. Historicamente, muitas vezes, a apropriação privada de terras públicas se deu fora dos requisitos legais, porém, foi legitimada, entre outros fatores, por se pautar na lógica de apropriação privada pretensamente produtiva. Desse modo, conforme se intentou demonstrar, busca-se uma naturalização da propriedade privada a tal ponto que se permite, a partir destes marcos jurídicos, inclusive o questionamento do reconhecimento de Terras Indígenas, mesmo estas sendo garantidas pela Constituição Federal de 1988 enquanto direito originário dos povos indígenas que as ocupam. 
Os Guarani do litoral norte de Santa Catarina: tensões entre o uso da terra e a propriedade privada capitalista, pp. 127-157.

\section{Referências bibliográficas}

CAMPOS, N. J. de. Usos e formas de apropriação da terra na Ilha de Santa Catarina. Geosul, Florianópolis, v. 17, n. 34, p. 113-135, jul./dez. 2002.

CARVALHO, M. J. A. de. Relatório Circunstanciado de Identificação e Delimitação da Terra Indígena Tarumã - SC. Funai, 2004a.

Relatório Circunstanciado de Identificação e Delimitação da Terra Indígena Morro Alto - SC. Funai, 2004b.

Relatório Circunstanciado de Identificação e Delimitação da Terra Indígena Pindoty - SC. Funai, 2004C.

CONSELHO NACIONAL DE GEOGRAFIA; CONSELHO NACIONAL DE ESTATÍSTICA. Enciclopédia dos municípios brasileiros. Rio de Janeiro: IBGE, 1957-64.

DANTAS, F. Relatório de viagem da FUNAI, Processo n. 175/1989.

DARELLA et al. Componente Indígena do Estudo de Impacto Ambiental. Relatório de Impacto do Meio Ambiente. Duplicação da Rodovia BR 280 - Trecho São Francisco do Sul - Jaraguá do Sul/Santa Catarina, Ilha de Santa Catarina, 2010.

Aldeias, terras e índios Guarani no litoral centro-norte de Santa Catarina e a BR-101 (GTs Portarias n. 641/PRES-699/PRES e 922/PRES/1998). Relatório Final. Florianópolis: UFSC, 1999.

FARIA, C. S. A integração precária e a resistência indígena na periferia da metrópole. 2008. 152 f. Dissertação (Mestrado em Geografia Humana) - Faculdade de Filosofia, Letras e Ciências Humanas da Universidade de São Paulo, São Paulo, 2008.

; OLIVEIRA, A. U. de. O processo de constituição da propriedade privada da terra no Brasil. In: Encontro de Geógrafos da América Latina, Montevidéu, 12, 2009. Anais... Montevidéu, Uruguai: EGAL, 2009. Disponível em: <http://www.egal2009.com/>. Acesso em: 10 jan.2010.

FICKER, C. História de Joinville: crônica da colônia Dona Francisca. Joinville: Letradágua, 2008.

FINDLAY, E. A. G. A ocupação territorial do município de Araquari em Santa Catarina. 2007. Disponível em: <http://anpuh.org/anais/wpcontent /uploads/mp/pdf/ANPUH.S24.0443.pdf>. Acesso em: 10 abr.2014.

As disputas de terras no Termo de São Francisco Xavier de Joinville. In: Simpósio Nacional de História, São Paulo, XXVI, 2011. Anais...

São Paulo: ANPUH, 2011. Disponível em: <http://www.anpuhsc.org.br/rev\%20front\%2020\%20vers\%20fin/f20 $\% 20$ artigos $\% 20$ consider\%20baia\%20b abitonga_eleide\%20findlay.pdf>. Acesso em: 28 nov. 2013. 
Considerações acerca da distribuição de terras na região da Baía da Babitonga. Fronteiras: Revista Catarinense de História, Florianópolis, ANPUH, n. 20, 2012. Disponível em: <http://anpuh.org/anais/wpcontent/uploads/mp/pdf/ANPUH .S24.0443.pdf>. Acesso em: 10 maio2014.

GUEDES, S. P. L. de C. A escravidão em uma colônia de "alemães". In: Simpósio Nacional de História, São Leopoldo, RS, XXIV, 2007. Anais... São Leopoldo: ANPUH, 2007. Disponível em: <http://anpuh.org/anais/? $\mathrm{p}=14932$ >. Acesso em: 28 nov. 2013.

JUÍZO FEDERAL DA 4a VARA FEDERAL DE JOINVILLE. Processo referente à demanda que se julga procedente porque tolhidos os autores no tocante ao uso, ao gozo e à disposição do imóvel pela delonga do Poder Público no concluir o processo de demarcação das terras indígenas. 2008. Disponível em: <http://trf4.jusbrasil.com.br/jurisprudencia/8918148/apelacao-civel-ac-4004-sc20027201004004-6-trf4/inteiro-teor-14060951>. Acesso em: 10 set. 2014.

LOPES, J. R. B. O ajustamento do trabalhador à indústria: mobilidade social e motivação. In: Mobilidade e Trabalho: um estudo na cidade de São Paulo. Rio de Janeiro: Centro Brasileiro de Pesquisas Educacionais, 1960. p. 360-440. (Série VIII - Pesquisas e Monografias - vol. 1)

MALINA, L. L. A territorialização do monopólio no setor celulísticopapeleiro: a atuação da Veracel Celulose no Extremo Sul da Bahia. 2013. 358 f. Dissertação (Mestrado) - Faculdade de Filosofia, Letras e Ciências Humanas da Universidade de São Paulo, São Paulo, 2013.

MARTINS, J. S. Expropriação e Violência: a questão política no campo. São Paulo: Hucitec, 1980.

Não há terra para plantar neste verão: o cerco das terras indígenas e das terras de trabalho no renascimento político do campo. Petrópolis: Vozes, 1986.

O cativeiro da terra. 8. ed. São Paulo: Hucitec, 2004.

- 0 poder do atraso: ensaios de sociologia da história lenta. São Paulo: Hucitec, 1994.

MARX, K. O Capital: crítica da economia política. Volume I. São Paulo: Abril Cultural, 1984. (Os economistas).

O Capital: crítica da economia política. Volume III. São Paulo: Abril Cultural, 1986. (Os economistas).

OLIVEIRA, A. U. de. A fronteira Amazônica mato-grossense: grilagem, corrupção e violência. 1997. 496 f. Tese (Livre-Docência em Geografia) - Faculdade de Filosofia, Letras e Ciências Humanas da Universidade de São Paulo, São Paulo, 1997.

. A política de reforma agrária no Brasil. In: SYDOW, E.; MENDONÇA, M. L. (org.) Direitos Humanos no Brasil 2009. São Paulo: Rede Social de Justiça e Direitos Humanos, 2009. p. 27-38. [Relatório Rede Social de Justiça e Direitos Humanos]. 
Modo capitalista de produção, agricultura e reforma agrária. São Paulo: FFLCH/LABUR Edições, 2007. 185 p. Disponível em:<http://www.fflch.usp.br/dg/gesp/baixar/livro_aviovaldo.pdf > . Acesso em: 8 maio 2010.

LADEIRA, M. I. O caminhar sob a luz: Território Mbya à beira do oceano. São Paulo: Ed. Unesp, 2007.

RAMOS, G. C. P. A formação do território de Santa Catarina com base na concessão de terras públicas. 2006, 269 p. Tese (Doutorado em Engenharia Civil) - Programa de Pós-Graduação em Engenharia Civil, Universidade Federal de Santa Catarina, 2006.

SILVA, A. M.; PERINI, C.G; AGOSTINI, M. de S. P. Histórias de bugues e tigres: corpo e natureza em terras catarinenses no século XIX. ProPosições, Campinas, Unicamp, v. 14, n. 2 (41) - maio/ago. 2003.

SILVA, L. O. Os indígenas da América, a propriedade privada e a construção dos "espaços vazios".XIII Congresso Internacional de História Econômica, Buenos Aires, Argentina, jul. 2002. Disponível em: <http://www.eco.unicamp.br/artigos/artigo289.htm>. Acesso em: 20 ago. 2014.

. Terras devolutas e latifúndio. Campinas: Ed. Unicamp, 1996.

SoUZA, J. G. de. A questão indígena: acumulação por espoliação e monopolização do território (A economia política do agronegócio). Prim@ Facie, João Pessoa, UFPB, v. 12, p. 1-42, 2014. 